\title{
Self-Attitude as a Psychological Component of the Personal Development of a Modern Teenager
}

\section{Самоставлення як психологічний компонент особистісного розвитку сучасного підлітка}

Nataliia Dmytriiuk

Ph.D. in Psychology,

Assistant Professor
Наталія Дмитріюк

кандидат психологічних наук, доцент

E-mail:dm.ns@ukr.net

orcid.org/0000-0002-8739-7965

Researcher ID: D-8671-2019

Lesia Ukrainka Eastern

European National University,

Lutsk, Ukraine

9, Potapova str.,

Lutsk, 43025

Nataliia Kordunova

Ph.D. in Psychology,

Assistant Professor
Східноєвропейський національний університет ілені Лесі Українки, м. Луиьк, Україна вул. Потапова, 9 , м. Луцьк, 43025

Наталія Кордунова кандидат психологічних наук, доцент

E-mail:dm.ns@ukr.net orcid.org/0000-0002-8739-7965

Researcher ID: D-8671-2019

Lesia Ukrainka Eastern European National University, Lutsk, Ukraine 9, Potapova str., Lutsk, 43025
Східноєвропейський національний університет ілені Лесі Українки, м. Луиьк, Україна вул. Потапова, 9 , м. Луцьк, 43025 
Original manuscript received April 23, 2019

Revised manuscript accepted May 14, 2019

The author's contribution: N. Dmytriiuk $-50 \%$, N. Kordunova $-50 \%$. Авторський внесок: Н. Дмитріюк $-50 \%$, Н. Кордунова $-50 \%$.

\section{ABSTRACT}

The article presents the results of an empirical study of the problem of self-attitude as a psychological component of the personal development of a modern teenager. The main features and preconditions of the development of self-attitude are described. It is found out that the internal experience of a person is filled by the internal picture of the person's representations about himself and is necessary for its qualitative existence in the environment, in fact, it fills its external experience. It is proved that the problem of adolescent self-attitude deserves a special attention, since inadequate perception of own personality, in this age period, can negatively affect the personal development of a young person. It is found that the majority of studied adolescents has the prevailed adequate level in the development of self-attitude. It is proved that significant changes take place in the development of self-attitude in the adolescence. It is substantiated that the peculiarity of adolescence is the formation of independent representations about oneself and others. It is empirically confirmed that teenagers in general take their own personality and adequately treat themselves. They have a considerable interest in themselves, a desire to know and improve themselves. It is shown that self-development in adolescence takes place against the background of accepting oneself and a holistic positive attitude toward oneself. Teenagers who tend to attribute responsibility for all events to external factors have been identified. It is shown that this leads to the development of a sense of misunderstanding of oneself, a rejection that violates the processes of balance of mental development, provokes internal conflicts of personality. It is empirically discovered that teenagers' self-attitude depends on the attitude of adults to them, and above all - parents. It is revealed that a teenager learns the values, the parameters of assessments and self-esteem that his parents value and on which he begins to evaluate himself, as well as the image of himself who owns or does not possess those or other qualities and features.

It is shown that the weak manifestations of the positive attitude of adults, reduce the need of adolescents in the positive adoption of their own personality. The importance of adults in understanding and accepting adolescents as they are, with their achievements and mistakes, is proved. The manifestations 
of undervalued self-esteem and inadequate reasoning about their own traits are diagnosed. All this creates a situation of misunderstanding of oneself and determines the need for personal changes. The formation of a positive attitude of teenagers to themselves involves the ability to feel personal comfort, a sense of pride, self-esteem, respect. The formation of personal "Me», selfdevelopment takes place against the background of self-acceptance and a holistic positive attitude towards oneself.

Key words: personality, self-attitude, personal development, teenager, self-esteem, self-development, positive attitude, balance of mental development.

\section{Вступ}

Суспільні трансформації, що відбуваються в нашій країні, сприяють підвищенню уваги до проблеми особистості та їі становлення. Водночас одним із найважливіших чинників формування різнобічно розвиненої особистості є ставлення до себе. Проблема ставлення особистості до себе, або самоставлення, в психології є актуальною і до цього часу викликає інтерес у дослідників. Самоставлення є необхідним компонентом розкриття потенційних можливостей особистості, створення умов для повного її включення у життя. Адекватне ставлення людини до самої себе є запорукою благополучного функціонування людини як суб’єкта суспільних відносин.

Психологічна природа ставлення достатньо складна i різноманітна. У сучасній психологї̈ відсутній єдиний підхід щодо визначення такого феномену, як «самоставлення». Аналіз робіт, присвячених вивченню ставлення людини до самої себе, дає змогу віднайти велике розмаїття психологічних категорій. У цьому контексті можна виокремити такі поняття, як: "узагальнена самооцінка», «самоповага», «самосприйняття», «емоційно-ціннісне ставлення», «власне самоставлення», «почуття власної гідності», «самовпевненість», «самозадоволення», «аутосимпатія», «самоцінність» тощо. Окрім того, більшість дослідників значення наведених термінів не розмежовують, а вживають як синоніми. 
Теоретичні та різні прикладні аспекти категорії «ставлення до себе» певною мірою розкривають у своїх працях зарубіжні та вітчизняні дослідники. Однак найбільш глибокий і багатосторонній аналіз проблем ставлення здійснено у працях В. М. М'ясищева, який розглядає це поняття як базову категорію психології і як вихідну одиницю психологічного аналізу (М'ясищев, 1998). М. І. Сарджвеладзе ж у своїх дослідженнях підкреслює, що модус існування особистості визначається включенням у соціальні стосунки та здібністю самої людини визначати ставлення до зовнішнього світу та до себе. На думку автора, «Я» існує саме тому, що воно є одночасно і суб'єктом, і об'єктом ставлення, а самість - це засіб відношення до себе (Райгородський, 2000).

Дослідження багатьох учених продемонстрували, що самоставлення слід розуміти: як одне з основних складників ядра особистості; як складову самоусвідомлення; як характеристику самоцінності; як механізм керування поведінкою; як стійке почуття особистості; як своєрідну особистісну рису, що слабо змінюється від ситуації до ситуації та навіть від віку до віку (Титаренко, 2001).

Загалом переважна більшість досліджень проблеми самоставлення особистості спирається на базове положення Б. Г. Ананьєва щодо ролі ставлення індивіда до себе як найважливішого чинника виникнення і стабілізації єдності в особистісному розвитку (Ананьєв, 1980).

Підсумовуючи сказане вище, можна констатувати, що самоставлення посідає особливе місце в системі розвитку та функціонування особистості. Воно є «одним зі складників суб’єктного ядра особистості та структури її самосвідомості, виражає особливості ставлення людини до самої себе і забезпечує центрування її внутрішнього простору й формування смислового вектора її життєвого шляху» (Мацевко, 2010: 210).

Водночас сучасний етап розвитку суспільства є доволі складним. Результати науково-теоретичного вивчен- 
ня проблематики формування та розвитку особистості у підлітковому віці визначають його особливу вразливість. Підлітковий вік - це вік між дитинством і дорослістю (від 11-12 до 14-15 років), який характеризується якісними змінами.

На етапі підліткового розвитку відбувається формування якісних новоутворень, що виникають унаслідок перебудови організму, його фізіологічних змін, ламання старих психологічних структур, утворення нових і більш прогресивних, трансформації взаємостосунків із дорослими й однолітками, зміни інтересів, мотивів, морально-ціннісних орієнтацій, засвоєння способів соціальної взаємодії, характерних для світу дорослих.

Отож, підлітковий вік характеризується розвитком самосвідомості, вольової сфери, мотивації, а також саме в цьому віці відбувається становлення та розвиток такого важливого компонента особистості, як самоставлення (Божович, 1968). Позитивне прийняття й адекватне ставлення до себе дозволяє чинити опір негативним впливам соціального середовища, підвищує самооцінку та дає змогу гармонійно розвиватися і прогнозувати бажане майбутнє (Гольдштейн, 2003). Але процес самоставлення часто супроводжується негативним самоприйняттям у підлітковому віці, що породжує певні негативні тенденції у розвитку, а саме занижену самооцінку, невпевненість у собі, тривожність, емоційну вразливість, загострену чутливість до критики (Горбатих, 2010).

Підлітки є надзвичайно сенситивними щодо дії різноманітних негативних впливів. Тому актуальною постає проблема вивчення самоставлення як інтегративного компонента розвитку особистості саме в підлітковому віці (Чамата, 1965).

Отже, проблема підліткового самоставлення заслуговує особливої уваги науковців, оскільки неадекватне прийняття власної особистості, саме в цей віковий період, 
може негативно позначитися на особистісному розвитку молодої людини.

Мета статті - здійснити аналіз впливу самоставлення на особистісний розвиток сучасного підлітка.

\section{Завдання статті}

1. Здійснити теоретичний аналіз ролі самоставлення в особистісному зростанні сучасних підлітків.

2. 3'ясувати психологічні особливості впливу самоставлення на психічний розвиток особистості у підлітковому віці.

3. Розкрити емпіричні показники явища самоставлення у сучасних підлітків і специфіку різних аспектів неприйняття в особистісному розвитку.

\section{Методи та методики дослідження}

В емпіричному дослідженні проблеми самоставлення взяли участь 80 підлітків (41 хлопець і 39 дівчат) віком від 14 до 15 років. Вибірка може бути охарактеризована як зручна, оскільки в неї були включені учні підліткового віку, які погодилися взяти участь в експерименті. Дослідження проводилось серед учнів загальноосвітніх шкіл м. Луцька. Для досягнення поставлених задач ми використовували метод бесіди, що застосовувався з метою встановлення контакту з досліджуваними. За допомогою цього методу була зібрана первинна інформація про досліджуваних. Також ми використали метод спостереження, що дав нам змогу отримати додаткові дані про особливості поведінки підлітків у різних життєвих ситуаціях, їх мотивацію та особливості відносин у колективі однолітків.

Для дослідження особливостей самоставлення підлітків, виявлення різних аспектів прийняття-неприйняття ми провели емпіричне дослідження. Відповідно до його завдань підібрано психодіагностичний інструментарій. Нами було обрано методику діагностики (тест-опитувальник, розроблений Е. Ф. Бажиним на основі шкали локусу конт- 
ролю Дж. Роттера), що використовувалася нами з метою виявлення рівня сформованості суб'єктивного контролю (РCK).

Поняття локусу контролю було визначено американським психологом Джуліаном Роттером. Говорячи про локус контролю особистості, мають на увазі схильність людини бачити джерело керування своїм життям або в зовнішньому середовищі, або в собі. За Дж. Роттером, існує два типи локусу контролю: інтернальний та екстернальний. Інтернальний локус контролю визначається тоді, коли людина здебільшого приймає відповідальність за події, що відбуваються у їі житті, на себе, пояснюючи їх своєю поведінкою, тоді як інтернали - характером. Екстернальний локус контролю свідчить про те, що людина схильна приписувати відповідальність за все, що відбувається, зовнішнім чинникам: іншим людям, долі або випадковості, навколишньому середовищу. Отож, РСК пояснює та відображає особистісне самоставлення як відчуття власної сили, достоїнства, відповідальності за те, що відбувається, самоповагою, соціальною зрілістю та самостійністю особистості.

У ході дослідження нам було важливо виявити особливості самоставлення підлітків у близьких, значущих взаєминах. 3 огляду на це, кожен із нас постійно впливає на інших людей, оскільки й інші впливають на нас. У цьому сенсі будь-яка комунікація є взаємозалежною. Базуючись на оцінках і ставленнях інших, цей аспект визначає успішність соціалізації особистості, самоставлення набуває тут важливого значення, оскільки процес формування особистості підліткового віку досить складний і суперечливий. Для дослідження самоставлення в міжособистісній залежності у підлітків нами була використана психодіагностична методика «Опитувальник міжособистісної залежності» Р. Гіршфільда (Макушина, 2006).

Проблема залежних стосунків постає тоді, коли такий взаємний вплив робить людину нещасною, соціально па- 
сивною, тобто нівелює позитивне ставлення особистості до себе. Лише у діалозі з найближчим оточенням особистість має можливість якнайповніше реалізувати себе та завдяки зворотному зв' язку структурувати себе в комунікативному процесі як особистість з адекватним самоставленням.

Опитувальник міжособистісної залежності може бути використаний як в індивідуальній, так і в груповій формі діагностики. Виконання опитувальника не вимагає обмеження в часі. У груповій формі воно займає, як правило, 15-20 хвилин. Опитувальник складається із 48 тверджень, які розподіляються за трьома шкалами: емоційна опора на інших (EO) (Emotional Reliance on Others, 18 запитань); невпевненість у собі (H) (Lack of Self-Confidence, 16 запитань); прагнення до автономії (A) (Assertion of Autonomy, 14 запитань). Підсумкове значення залежності (3) підраховується шляхом додавання отриманих балів за першими двома шкалами і вираховування з цієї суми балів, отриманих за третьою шкалою: $3=\mathrm{EO}+\mathrm{H}-\mathrm{A}$.

Дані, отримані за допомогою вказаних методів і методик, підлягали кількісному та якісному аналізу.

\section{Результати та дискусії}

Перейдемо до розгляду дослідження самоставлення як чинника розвитку особистості підліткового віку. За методикою діагностики рівня суб'єктивного контролю Дж. Роттера до уваги брали показники, що свідчили про наявність того чи іншого виду інтернальності у структурі поведінки підлітка. Отримані кількісні результати наведено у вигляді діаграми (рис. 1).

Шкала 1. Інтернальність у сфері досягнень. Високі показники за цією шкалою відповідають високому рівню суб'єктивного контролю над емоційно позитивними подіями та ситуаціями. Такі підлітки вбачають у собі основний «осередок» керування власним життям. Так, у 62,5\% підлітків переважаючим є інтернальний локус контролю, що засвідчує високу міру відповідальності за події, які відбу- 
ваються в їхньому житті, можливість самостійно досягати поставленої мети. Досліджувані підлітки з інтернальним локусом контролю краще працюють наодинці, ніж під наглядом. Інтернали менш схильні підкорятися тиску інших, чинити опір, якщо відчувають, що ними маніпулюють, вони реагують сильніше, ніж екстернали, на втрату особистісної свободи. Інтернали активніше шукають інформацію і, зазвичай, більш обізнані про ситуацію.

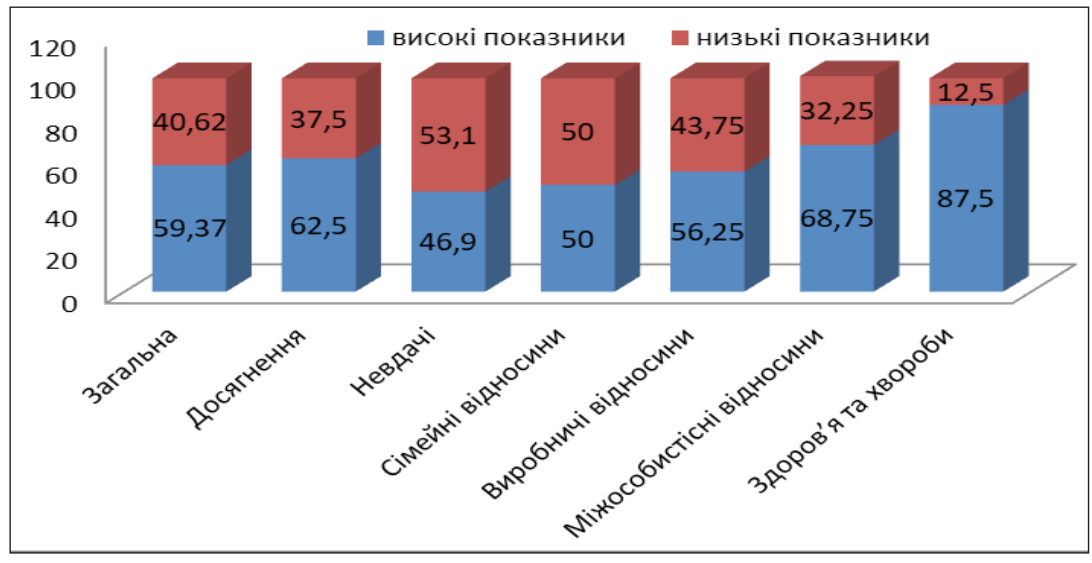

Puc. 1. Динаміка розподілу результатів рівня суб’єктивного контролю підлітків

Також у $37,5 \%$ підлітків виявлено низькі показники, що свідчить про те, що в особистісному розвитку сучасного підлітка простежується здатність приписувати власні успіхи та досягнення зовнішнім обставинам - везінню, щасливій долі або допомозі інших людей.

Шкала 2. Інтернальність у сфері невдач. Високі показники за цією шкалою свідчать про розвинуте почуття суб'єктивного контролю відносно негативних подій і ситуацій, що проявляється у схильності звинувачувати самого себе в різноманітних невдачах і неприємностях. За шкалою інтернальності у сфері невдач виявлено високі показники $(46,9 \%)$, що характеризує більшість опитаних як осо- 
бистостей із високим рівнем суб'єктивного контролю. Це свідчить про їх відповідальність за результати діяльності навіть у негативних ситуаціях.

Низькі показники за цією шкалою виявлено у 53,1\% підлітків, що свідчить про їх схильність приписувати відповідальність за негативні події іншим людям або вважати їх наслідком невезіння.

Шкала 3. Інтернальність у сфері сімі і стосунків із батьками. Високі показники свідчать про те, що особистість вважає свої дії важливим чинником формування сімейних стосунків, почувається здатною суттєво впливати на сімейну ситуацію та визначати власний особистісний розвиток в умовах сімейного виховання. Низькі показники вказують на те, що особистість не схильна брати на себе відповідальність за сімейну атмосферу, за те, як складаються стосунки з батьками.

Показники за шкалою сімейних відносин як інтернальності, так і екстернальності розділились порівну (50\%). Це вказує на незначний досвід підлітків у подружніх сімейних стосунках, а також свідчить про відчуття власної відповідальності за події, які відбуваються у сфері сімейних стосунків і взаємин із батьками.

Шкала 4. Інтернальність у сфері виробничих відносин. Високий показник свідчить про те, що особистість почувається здатною контролювати ситуацію власної успішності у навчанні та спілкуванні з викладачами. Для виробничих відносин характерні високі показники інтернальності $(68,75 \%$ ) -підлітки є досить комунікабельними. Усі прагнуть і вміють спілкуватися, налагоджувати міжособистісні відносини один з одним.

Низький показник $(43,75 \%)$ характеризує особистостей, які схильні перекладати відповідальність за результати власної навчальної діяльності та спілкування з викладачами на зовнішні обставини і самих викладачів. що може свідчити про ще не достатньо сформований рівень розвитку відповідальності за власні учбові та професійні успіхи 
або невдачі, у цьому випадку необхідно використовувати здатність до саморегуляції у навчальному процесі.

Шкала 5. Інтернальність у сфері міжособистісних відносин. Високий показник виявлено у 68,75\% досліджуваних підлітків, що свідчить про те, що підлітки спроможні контролювати власні неформальні стосунки з оточуючими, викликати до себе повагу і симпатію, заводити друзів.

На противагу цьому 32,25\% підлітків мають низький показник за шкалою інтернальності у сфері міжособистісних відносин. Підлітки не почувають себе здатними активно формувати власне коло спілкування, свої стосунки, а вважають їх результатом дій і впливу на них оточуючих.

Шкала 6. Інтернальність у галузі здоров'я та хвороб. Високий показник притаманний 87,5\% підлітків. 12,5\% досліджуваних мають низький показник. Отже, більшість досліджуваних постійно схильні брати на себе відповідальність за стан власного здоров'я і захворювання, власні здорові та шкідливі звички і спосіб життя. У сучасному світі популяризується здоровий спосіб життя, при цьому кожен розуміє, що покращення свого здоров'я залежить від особистісних старань і зусиль. Багато сучасних підлітків займаються фітнесом, відвідують тренажерні зали. В учнівінтерналів виявлена більш активна позиція стосовно власного здоров'я: вони краще інформовані про свій фізичний стан, більше піклуються про себе і частіше звертаються за профілактичною комплексною медичною допомогою.

3 іншого боку, низькі показники свідчать про нездатність до свідомого контролю стану власного здоров' я, власної поведінки відносно здоров'я, схильність не брати на себе відповідальність за хвороби й одужання. Низькі показники свідчать про те, що такі підлітки вважають хворобу випадковістю та сподіваються, що одужання можливе лише за допомогою оточуючих.

Шкала загальної інтернальності. Високий показник за цією шкалою свідчить про високий рівень суб’єктивного контролю над ситуаціями (самоставлення). Особистість із 
високим показником вважає, що більшість важливих подій у її житті - це результат її власних дій, що вона спроможна до управління своїм життям, відчуває власну відповідальність за події і за те, як складається життя загалом. Низький показник за цією шкалою свідчить про низький рівень суб'єктивного контролю. Особистість із низьким показником не виявляє зв'язку між власними діями і значущими подіями свого життя, не вважає себе здатною контролювати їх розвиток і вважає, що результати діяльності отримано завдяки випадку або діям із боку інших людей.

Аналізуючи загальний результат за методикою, можна стверджувати, що 59,37\% підлітків відповідальні за події свого життя. А показники екстернальності виявлено у 40,62\% підлітків, які схильні приписувати відповідальність за всі події зовнішнім чинникам (іншим людям, нагоді, долі тощо).

Аналізуючи загальний результат за методикою, можна стверджувати, що в першому випадку підлітки відчувають себе активним суб'єктом самоставлення, долають негативні хвилювання за рахунок зниження їх значущості й емоційного реагування на них за допомогою інтелектуальних прийомів. У другому випадку досліджувані підлітки відчувають себе пасивним суб'єктом самоставлення.

Наступним етапом нашого дослідження був аналіз даних за методикою «Опитувальник міжособистісної залежності» Р. Гіршфільда. Міжособистісна залежність - це сфера, що перебуває у фокусі уваги психологів. Саме через усвідомлення відношень та оцінок оточуючих людина пізнає й оцінює саму себе, а також засвоює певні вимоги суспільства (Гнєзділова, 2002).

Провівши емпіричне дослідження характеристик міжособистісних відносин, особистісних чинників успішності або труднощів у спілкуванні сучасних підлітків, можемо констатувати, що серед досліджуваних підлітків поширена проблема міжособистісних стосунків. Ця проблема включає різноманітні залежності у досліджуваних, наприклад, 
емоційну залежність та опору на інших людей. Залежність від інших - це природне явище в будь-яких відносинах. Усі ми тією чи іншою мірою виявляємо залежність один від одного. Залежність стає проблемою тоді, коли стає надмірною.

Розглянемо детальніше отримані результати опитувальника міжособистісної залежності за такими чотирма шкалами, як: емоційна опора на інших, невпевненість у собі, прагнення до автономії та залежність (рис. 2).

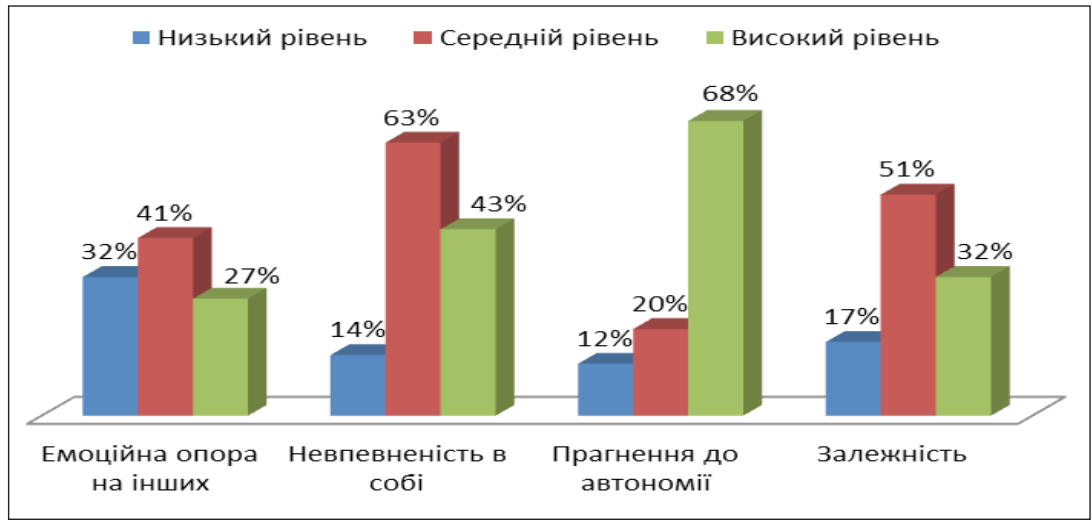

Puc. 2. Результати відсоткового розподілу міжособистісної залежності у підлітків

Нами були отримані такі дані. За шкалою «ммоційна опора на інших" визначено перевагу середнього рівня, тобто адекватне самоставлення, і це є найвищий показник, притаманний для $41 \%$ підлітків. Отож, сучасні підлітки розраховують на емоційну підтримку від інших людей, виявляють спрямованість на отримання схвальної оцінки дорослих, покладають великі очікування на дорослих. Середній рівень отриманих показників свідчить про чутливість до несхвалення і критики з боку оточуючих, потребу в близьких людях, тривогу з приводу їх можливої втрати.

Шкала «Невпевненість у собі» також визначила, що у досліджуваних осіб домінуючим є середній рівень вираже- 
ності. Підлітки, у яких виражена невпевненість у собі, тобто неприйняття власної особистості, не можуть себе розвивати у повній мірі: для них украй важко пристосовуватися до інших, розбиратися у собі, своїх почуттях і проблемах, вони здійснюють необгрунтовані та поспішні висновки і припущення щодо людей і так само поводять себе у дискусіях. Упевненість у собі надає підлітку можливість сміливо долати всі проблеми й невизначеності життя, а також стійко сприймати всі розчарування, злети й падіння. Позитивна самооцінка i, як наслідок, адекватне самоприйняття допоможуть сучасному підлітку домогтися своїх прагнень і здійснити задумане в житті. Крім того, почуття власної гідності, адекватного ставлення до власної особистості допомагає підлітку налагодити взаємозв'язок і взаємини, успішно розвиватися й стати внутрішньо сильною особистістю.

За шкалою «Прагнення до автономії» високий рівень розвитку було виявлено у $68 \%$ досліджуваних підлітків. Такі показники свідчать, що головним стає прагнення підлітка до особистісної автономії у колі ровесників і пошук визнання цінності власної особистості в очах однолітків. У багатьох підлітків виявляється фрустрованою потреба «бути значущими в очах ровесників», що призводить до переживань. Важливість для сучасного підлітка його спілкування з ровесниками нерідко відсуває на задній план його стосунки з дорослими, передусім із батьками та вчителями. Чим старшими стають сучасні підлітки, тим менше розуміння та підтримки вони знаходять у дорослих. Іншими словами, батьки припиняють бачити своїх дітей, а вчителі - своїх учнів, а місце цих конкретних і різних молодих сучасних людей починає посідати абстрактна і спотворена їхня версія, взята із соціальних мереж Інтернету. Перше джерело цих проблем - нерозуміння дорослими внутрішнього світу сучасного підлітка, їхні хибні або примітивні уявлення про його переживання, мотиви тих чи інших учинків, прагнень, цінностей. 
Аналізуючи результати спостереження, бесіди й анкетування, ми зробили певні висновки: сучасні підлітки вважають, що батьки і вчителі, здебільшого, не вміють побачити і враховувати у практиці виховання того швидкого, інтенсивного процесу дорослішання сучасного підлітка, зберігаючи «дитячі» форми контролю, спілкування 3 дітьми. Саме цей момент підлітки, починаючи з 6-го класу, називають головним чинником своїх прикростей у спілкуванні з батьками. Особливо гостро це виявляється у старших класах, учні яких мають велику потребу в спілкуванні з дорослими «на рівних» і рідко мають можливість її задовольнити. Наслідком цього, як правило, стає протиставлення себе, свого «Я» дорослим, тобто потреба в особистісному прийнятті.

Потреба сучасних підлітків у тому, щоб дорослі, особливо батьки, визнали їх рівноправними партнерами у спілкуванні, породжує конфлікти. Цікаво, що винним у конфлікті завжди визнається підліток - так вважають, до речі, й самі підлітки. Подібну самозвинувачувальну позицію сучасних підлітків деякі психологи називають «психологічним примиренням», пов'язуючи їі з прийняттям формальних відносин «слухняності», що нав’язуються їм, ламання позиції «психологічного примирення» найчастіше призводить до «психологічного бунту» (Гнєзділова, 2002: 44). Коли виникає такий «психологічний бунт», дорослі починають бити на сполох, ідуть до психолога, шукають вихід, а «психологічне примирення» всіх влаштовує. Водночас подібне ставлення до конфліктів, за якого дорослі стійко посідають зовнішню звинувачувальну позицію, а сучасні підлітки - самозвинувачувальну, є неконструктивним і не формує адекватного емоційно-ціннісного ставлення до себе.

Відзначимо ще один момент, на який варто звернути увагу. Батьки, які спостерігають дорослішання своїх дітей, найчастіше помічають у такому процесі тільки негативні сторони: підліток стає «неслухняним», «потайливим» 
тощо - і зовсім не помічають позитивного, нового. Одним із таких напрямків є розвиток у підлітковому віці прагнення допомогти дорослим, підтримати, розділити їхнє горе або радість. Дорослі готові, у кращому випадку, виявити співчуття до підлітка, але зовсім не здатні прийняти подібне ставлення з його боку. Зрозуміло, чому саме так виходить: для того, щоб прийняти таке ставлення підлітка, якраз і необхідно бути з ним «на рівних». На нашу думку, багато актуальних проблем, пов'язаних із розвитком і вихованням сучасних підлітків, виникають тому, що дорослі прагнуть тільки щось дати підлітку, не бажаючи, та й не вміючи, нічого взяти. Але тільки через реальні вияви доброти і співчуття ці важливі й дуже дефіцитні особистісні якості можуть розвиватися.

У досліджуваних підлітків є виражена потреба в емоційній близькості, любові й прийнятті з боку значущих інших, прагнення до отримання допомоги і підтримки на тлі постійного відчуття себе як безпорадного і слабкого незалежно від ситуації. Невпевненість у собі, як ми бачимо 3 отриманих результатів за попередньою шкалою, свідчить про неприйняття себе, виникнення почуття безпорадності, тривоги з приводу можливого відторгнення і самотності. Саме ці чинники гальмують поштовх для розвитку і ствердження власного адекватного самоставлення у сучасних підлітків.

\section{Висновки}

Феномен самоставлення особистості має безліч особливостей, оскільки існує багато його тлумачень, а отже, i підходів до його визначення, вивчення. Внутрішній досвід людини наповнює власна особистісна картина уявлень про себе, що необхідно для якісного існування у середовищі, власне, це і забезпечує її становлення та розвиток.

Отримані результати емпіричного дослідження показують, що підлітки загалом приймають власну особистість (інтернальність 59,37\%), досить адекватно ставляться до 
себе. У них спостерігається неабиякий інтерес до власної особистості, бажання пізнати себе і вдосконалитися. Саморозвиток у підлітковому віці відбувається на тлі прийняття себе і цілісного позитивного ставлення до себе.

Проте, присутні показники екстернальності, які виявлено у 40,62\% підлітків, схильних приписувати відповідальність за всі події зовнішнім чинникам у ставленні до себе. У таких підлітків переважає негативне самоставлення. Це призводить до розвитку почуття нерозуміння себе, неприйняття, що порушує процеси збалансованості психічного розвитку, провокує конфлікти особистості.

Результати емпіричного дослідження показують, що самоставлення підлітків залежить від ставлення до них дорослих і перш за все - батьків. Підліток засвоює цінності, параметри оцінок і самооцінок, норм, за якими його оцінюють батьки та за якими він починає оцінювати себе сам, а також образ себе, який володіє або не володіє тими чи іншими якостями і рисами.

Водночас спостерігаються прояви заниженої самооцінки та недостатньо обгрунтованого уявлення про власні риси. Усе це створює ситуацію нерозуміння себе та детермінує потребу в особистісних самозмінах, і важливість формування позитивного ставлення підлітків до себе передбачає можливість відчувати особистісний комфорт, почуття гордості, власної гідності, поваги.

Із метою формування позитивного ставлення старших підлітків до самих себе, гармонізації їх особистості, бажання пізнати себе краще та вдосконалитися, варто організувати тренінг, який, на нашу думку, дасть змогу якісно підвищити рівень їх самоприйняття та самооцінки, сприятиме особистісному зростанню, що є перспективою подальших наукових розробок.

\section{Література}

Ананьев Б. Г. Избранные психологические труды. Москва : Педагогика, 1980. T. 1.230 c. 
Божович Л. И. Личность и ее формирование в детском возрасте. Москва : Просвещение, 1968. 235 с.

Гнєздилова М. У. Спілкування та поведінка підлітків. Психолог. 2002. № 38-39. С. 42-45.

Гольдштейн А. Тренінг умінь спілкування: як допомогти проблемним підліткам. Київ : Либідь, 2003. 520 с.

Горбатих В. В. Самоставлення особистості як емоційний компонент самосвідомості. Вісник Запорізького національного університету. Серія «Педагогічні науки». 2010. № 2 (13). С. 48-52.

Дригус М. Т. Проблема особистісної ефективності у контексті наукової спадщини Г. С. Костюка. Проблели сучасної психологї̈: Збірник наукових праць Кам'янець-Подільського національного університету ілені Івана Огієнка, Інституту психологї̈ ілені Г. С. Костюка НАПН України. Кам'янець-Подільський : Аксіома, 2016. Вип. 33. С. 148-161.

Эриксон Э. Идентичность: юность и кризис. Москва : Прогресс, 1996. 344 c.

Козуб Я. В. Специфіка ставлення до навчання у встигаючих та невстигаючих студентів з домінуванням різних видів мотивації досягнення. Проблели сучасної психології: Збірник наукових праць Кам'янець-Подільського національного університету ілені Івана Огієнка, Інституту психологї ілені Г. С. Костюка НАПН України. Кам'янець-Подільський : Аксіома, 2016. Вип. 32. С. 218-234.

Колодяжна А. В. Взаємозв'язок компонентів самоставлення з емоційними властивостями особистості залежно від їі творчих проявів: автореферат дисертації. Київ, 2012. 17 с.

Колышко А. М. Психология самоотношения. Гродно, 2004. 102 с.

Кон И. С. Родители и дети. Москва : Просвещение, 1989. С. 16-19.

Максименко С. Д. Генеза розвитку особистості. Київ : ТОВ «КММ», 2006. 240 c.

Макушина О. П. Методы психологического изучения девиантного поведения. Воронеж : Юнити-дана, 2006. 80 с.

Мацевко Н. Феномен самоставлення в психології. Психологія особисmocmi. 2010. № 1. С. 202-210.

Москаленко В. В. Соціалізація особистості: монографія. Київ : Фенікс, $2013.540 \mathrm{c}$.

Мясищев В. Н. Психология отношений: избр. психол. труды. Воронеж : Ин-т практ. психологии, 1998. 362 с.

Павелків Р. В. Вікова психологія: підручник. Київ : Кондор, 2015. 469 с. Петровский А. В., Ярошевский М. Г. Теоретическая психология. Москва : Академия, 2003. 496 с.

Прахова С. А. Роль індивідуально-типологічних та соціально-психологічних чинників у детермінації фрустраційних станів учнів різ-

(C) Nataliia Dmytriiuk, Nataliia Kordunova 
них вікових груп. Проблели сучасної психологї: Збірник наукових праць Кал'янець-Подільського національного університету ілені Івана Огієнка, Інституту психологї ілені Г. С. Костюка НАПН Украӥни. Кам'янець-Подільський : Аксіома, 2016. Вип. 32. C. 454-464.

Психологічні закономірності розвитку громадянської спрямованості особистості: монографія / За ред. М. Й. Боришевського; Ін-т психології ім. Г. С. Костюка АПН України. Київ : Міленіум, 2006. 297 c.

Райгородский Д. Я. Психология самосознания. Хрестоматия. Самара : Изд. дом «Бахрах-М», 2000.672 с.

Титаренко Т. М. Самоотношение. Психология личности: Словарь-справочник. Київ : Рута, 2001. С. 110.

Фрейд А. Введение в детский психоанализ. Норма и патология детского развития. «Я» и механизмы защит. Минск : ООО «Попурри», 2004. 448 c.

Чамата П. Р. Самосвідомість та її розвиток у дітей. Київ : Наука, 1965. $48 \mathrm{c.}$

Чудновский В. Э. Становление личности и проблема смысла жизни: избранные труды. Воронеж, 2006. 768 с.

Cohen, A. K., \& Chaffee, B. W. (2013). The relationship between adolescents' civic knowledge, civic attitude, and civic behavior and their self-reported future likelihood of voting. Education, Citizenship and Social Justice, 8 (1), 43-57.

Hart, D., Richardson, C., \& Wilkenfeld, B. (2011). Civic Identity. Handbook of Identity. Theory and Research. P. 771-787.

Marcia, J. E. (1966). Development and validation of ego-identity status. Journal of personality and social psychology, 3 (5), 551-558.

Taljunaite, M. (2013). From ethnic and civil identity towards state identity. Philosophy-Sociology, 24 (4), 187-192.

\section{References}

Anan'ev, B. G. (1980). Izbrannye psihologicheskie trudy [Selected psychological works ]. (Vol. 1). Moskva : Pedagogika [in Russian].

Bozhovich, L. I. (1968). Lichnost' $i$ eje formirovanie $v$ detskom vozraste [Personality and its formation in childhood]. Moskva : Prosveshchenie [in Russian].

Hniezdylova, M. U. (2002). Spilkuvannia ta povedinka pidlitkiv [Communication and behavior of adolescents]. Psykholoh-Psychologist, 38-39, 42-45 [in Ukrainian].

Holdshtein, A. (2003). Treninh umin spilkuvannia: yak dopomohty problemnym pidlitkam [Training of communication skills: how to help problem teens ]. Kyiv : Lybid [in Ukrainian]. 
Horbatykh, V. V. (2010). Samostavlennia osobystosti yak emotsiinyi komponent samosvidomosti [Self-attitude as an emotional component of self-consciousness]. Visnik Zaporizkoho natsionalnoho universytetu. Seriia "Pedahohichni nauky" - Newsletter of Zaporizhzhia National University. «Pedagogical Sciences», 2 (13), 48-52 [in Ukrainian].

Dryhus, M. T. (2016). Problema osobystisnoi efektyvnosti u konteksti naukovoi spadshchyny H. S. Kostiuka [The issue of personal efficiency in the context of scientific heritage of G. S. Kostiuk]. S. D. Maksymenko, L. A. Onufriieva (Eds.). Problemy suchasnoi psykholohii Problems of Modern Psychology: Collection of research papers of Kamianets-Podilskyi Ivan Ohienko National University, G. S. Kostiuk Institute of Psychology at the National Academy of Pedagogical Sciences of Ukraine, 33, 148-161. Kamianets-Podilskyi : Aksioma [in Ukrainian].

Jerikson, Je. (1996). Identichnost': junost' i krizis [Identity: youth and crisis ]. Moskva : Progress [in Russian].

Kozub, Ya. V. (2016). Spetsyfika stavlennia do navchannia u vstyhaiuchykh ta nevstyhaiuchykh studentiv $\mathrm{z}$ dominuvanniam riznykh vydiv motyvatsii dosiahnennia [Specifics of the high and low level academic progress students' attitude to the learning with domination of different types of achievement motivation]. S. D. Maksymenko, L. A. Onufriieva (Eds.). Problemy suchasnoi psykholohii-Problems of Modern Psychology: Collection of research papers of KamianetsPodilskyi Ivan Ohienko National University, G. S. Kostiuk Institute of Psychology at the National Academy of Pedagogical Sciences of Ukraine, 32, 218-234. Kamianets-Podilskyi : Aksioma [in Ukrainian].

Kon, I. S. (1989). Roditeli i deti [Parents and children]. Moskva : Prosveshchenie [in Russian].

Kolyshko, A. M. (2004). Psihologija samootnoshenija [Psychology of selfrelationship]. Grodno [in Russian].

Kolodiazhna, A. V. (2012). Vzaiemozviazok komponentiv samostavlennia z emotsiinymy vlastyvostiamy osobystosti zalezhno vid yii tvorchykh proiaviv [Interconnection of components of self-attitude with emotional properties of a personality depending on its creative manifestations]. Extended abstract of candidate's thesis. Kyiv [in Ukrainian].

Maksymenko, S. D. (2006). Geneza rozvytku osobystosti [Genesis of personality development]. Kyiv : TOV «KMM» [in Ukrainian].

Makushina, O. P. (2006). Metody psihologicheskogo izuchenija deviantnogo povedenija [Methods of psychological study of deviant behavior]. Voronezh : Juniti-dana [in Russian].

Matsevko, N. (2010). Fenomen samostavlennia v psykholohii [The phenomenon of self-attitude in psychology]. Psykholohiia osobystosti-Psychology of personality, 1, 202-210 [in Ukrainian]. 
Moskalenko, V. V. (2013). Sotsializatsiia osobystosti [Socialization of personality]. Kyiv : Feniks [in Ukrainian].

Mjasishchev, V. N. (1998). Psihologija otnoshenij: izbr.psihol.trudy [Psychology of Relationships: Selected Psychological Works]. Voronezh : In-t prakt. psihologii [in Russian].

Pavelkiv, R. V. (2015). Vikova psykholohiia [Age-related psychology]. Kyiv : Kondor [in Ukrainian].

Petrovskij, A. V., \& Jaroshevskij, M. G. (2003). Teoreticheskaja psihologija [Theoretical psychology]. Moskva : Akademija [in Russian].

Prakhova, S. A. (2016). Rol indyvidualno-typolohichnykh ta sotsialnopsykholohichnykh chynnykiv u determinatsii frustratsiinykh staniv uchniv riznykh vikovykh hrup [The role of individual typological and socio-psychological factors in determining the frustration of students of different age groups]. Problemy suchasnoi psykholohiiProblems of modern psychology: Collection of research papers of $\mathrm{Ka}$ mianets-Podilskyi Ivan Ohienko National University, G. S. Kostiuk Institute of Psychology at the National Academy of Pedagogical Sciences of Ukraine, 32, 454-464. Kamianets-Podilskyi : Aksioma [in Ukrainian].

Boryshevskyi, M. Y. (Ed.). (2006). Psykholohichni zakonomirnosti rozvytku hromadianskoi spriamovanosti osobystosti [Psychological regularities of the development of the civic orientation of the personality]. Kyiv : Milenium [in Ukrainian].

Rajgorodskij, D. Ja. (2000). Psihologija samosoznanija [Psychology of selfconsciousness ]. Samara : Izd. dom «Bahrah-M» [in Russian].

Titarenko, T. M. (2001). Samootnoshenie. Psihologija lichnosti [Self-relationship. Psychology of Personality]. Kyiv : Ruta [in Ukrainian].

Frejd, A. (2004). Vvedenie $v$ detskij psihoanaliz. Norma i patologija detskogo razvitija. «Ja» $i$ mehanizmy zashchit [Introduction to child psychoanalysis. Norm and pathology of child development. "I» and defense mechanisms ]. Minsk : OOO «Popurri» [in Russian].

Chamata, P. R. (1965). Samosvidomist ta yii rozvytok u ditei [Self-consciousness and its development in children]. Kyiv : Nauka [in Ukrainian].

Chudnovskij, V. E. (2006). Stanovlenie lichnosti i problema smysla zhizni [The formation of the personality and the problem of the meaning of life]. Voronezh [in Russian].

Cohen, A. K, \& Chaffee, B. W. (2013). The relationship between adolescents' civic knowledge, civic attitude, and civic behavior and their self-reported future likelihood of voting. Education, Citizenship and Social Justice, 8 (1), 43-57.

Hart, D., Richardson, C., \& Wilkenfeld, B. (2011). Civic Identity. Handbook of Identity. Theory and Research. 
Marcia, J. E. (1966). Development and validation of ego-identity status. Journal of personality and social psychology, 3 (5), 551-558.

Taljunaite, M. (2013). From ethnic and civil identity towards state identity. Philosophy-Sociology, 24 (4), 187-192.

\section{Дмитріюк Наталія, Кордунова Наталія. Самоставлення як психоло- гічний компонент особистісного розвитку сучасного підлітка}

\section{АНОТАЦІЯ}

У статті представлено результати емпіричного дослідження проблеми самоставлення як психологічного компонента особистісного розвитку сучасного підлітка. Охарактеризовано основні особливості та передумови розвитку самоставлення. З'ясовано, що внутрішній досвід людини наповнює внутрішня картина уявлень особистості про себе, що необхідно для якісного ії існування у середовищі, власне, це і наповнює ії зовнішній досвід. Доведено, що проблема підліткового самоставлення заслуговує особливої уваги, оскільки неадекватне прийняття власної особистості, саме у чей віковий період, може негативно позначитися на особистісному розвитку молодої людини. Виявлено, що у більшості досліджуваних підлітків переважає адекватний рівень розвитку самоставлення. Доведено, що у підлітковому віці у розвитку самоставлення відбуваються суттєві зміни. Обгрунтовано, що особливістю підліткового віку є формування самостійних уявлень про самого себе і про навколишніх. Емпірично підтверджено, що підлітки загалом приймають власну особистість і досить адекватно ставляться до себе. Уних спостерігається неабиякий інтерес до себе, бажання пізнати себе та вдосконалитися. Показано, що саморозвиток у підлітковому віці відбувається на тлі прийняття себе і цілісного позитивного ставлення до себе. Виявлено підлітків, які схильні приписувати відповідальність за всі події зовнішнім чинникам. Показано, що че призводить до розвитку почуття нерозуміння себе, неприйняття, що порушує процеси збалансованості психічного розвитку, провокує внутрішні конфлікти особистості. Емпірично виявлено, що самоставлення підлітків залежить від ставлення до них дорослих, перш за все, батьків. 3'ясовано, що підліток засвоює цінності, параметри оцінок і самооцінок, за якими його оцінюють батьки та за якими він починає оцінювати себе сам, а також образ себе, який володіє або не володіє тими чи іншими якостями і рисами. Показано, що слабкі прояви позитивного ставлення дорослих зменшують потребу підлітків у позитивному прийнятті власної особистості. Доведено важливість дорослих у розумінні та прийнятті 
підлітків такими, якими вони є, враховуючи їх досягнення та помилки. Діагностовано прояви заниженої самооцінки та недостатньо обгрунтованого уявлення про власні риси. Усе це створює ситуацію нерозуміння себе та детермінує потребу в особистісних самозмінах. Формування позитивного ставлення підлітків до себе передбачає можливість відчувати особистісний комфорт, почуття гордості, власної гідності, поваги. Становлення власного “Я», саморозвиток відбуваються на тлі прийняття себе і цілісного позитивного ставлення до себе.

Ключові слова: особистість, самоставлення, особистісний розвиток, підліток, самооцінка, саморозвиток, позитивне ставлення, збалансованість психічного розвитку.

\section{Дмитриюк Наталия, Кордунова Наталия. Самоотношение как психологический компонент личностного развития современного подростка}

\section{АННОТАЦИЯ}

В статье представлены результаты эмпирического исследования проблемы самоотношения как психологического компонента личностного развития современного подростка. Охарактеризованы основные особенности и предпосылки развития самоотношения. Выяснено, что внутренний опыт человека наполняет внутренняя картина представлений личности о себе, что является необходимым для качественного ее существования в среде, собственно, это и наполняет ее внешний опыт. Доказано, что проблема подросткового самоотношения заслуживает особого внимания, поскольку адекватное принятие собственной личности, именно в этот возрастной период, может негативно отразиться на личностном развитии молодого человека. Выявлено, что в большинства исследуемых подростков преобладает адекватный уровень развития самоотношения. Доказано, что в подростковом возрасте в развитии самоотношения происходят существенные изменения. Обосновано, что особенностью подросткового возраста является формирование самостоятельных представлений о самом себе и об окружающих. Эмпирически подтверждено, что подростки в иелом принимают собственную личность и достаточно адекватно относятся к себе. У них наблюдается большой интерес к себе, желание познать себя и усовершенствоваться. Показано, что саморазвитие в подростковом возрасте происходит на фоне принятия себя и целостного положительного отношения к себе. Выявлено подростков, склон- 
ных приписывать ответственность за все события внешним факторам. Показано, что это приводит к развитию чувства непонимания себя, неприятия, нарушает прочессы сбалансированности психического развития, провоцирует внутренние конфликты личности. Эмпирически установлено, что самоотношение подростков зависит от отношения к ним взрослых, прежде всего, родителей. Установлено, что подросток усвачвает иенности, параметры оценок и самооценок, по которым его оценивают родители и по которым он начинает оценивать себя сам, а также образ себя, который владеет или не владеет теми или иными качествами и чертами. Показано, что слабые проявления позитивного отношения взрослых уменьшают потребность подростков в положительном принятии собственной личности. Доказана важность взрослых в понимании и принятии подростков такими, какие они есть, учитывая их достижения и ошибки. Диагностированы проявления заниженной самооценки и недостаточно обоснованного представления о собственных чертах. Все это создает ситуацию непонимания себя и детерминирует потребность в личных самоизменениях. Формирование позитивного отношения подростков к себе предполагает возможность чувствовать личностный комфорт, чувство гордости, собственного достоинства, уважения. Становление собственного "Я», саморазвитие происходит на фоне принятия себя и целостного положительного отношения к себе.

Ключевые слова: личность, самоотношение, личностное развитие, подросток, самооценка, саморазвитие, позитивное отношение, сбалансированность психического развития. 